\title{
Kausalitas Bivariat antara Nilai Tukar Rupiah dan Indeks Harga Saham Gabungan
}

\author{
MuHAMMAD LUTHFI SETIARNO PUTERA \\ IAIN Palangka Raya, Jl. G. Obos Komplek Islamic Centre Palangka Raya \\ email: luthfi7731@gmail.com
}

\begin{abstract}
ABSTRAK
Nilai kurs dan indeks saham di suatu negara adalah beberapa indikator yang menjadi pertimbangan para pelaku usaha, pebisnis, investor dan negara rekanan dalam menentukan langkah dan keputusan yang krusial. Nilai tukar mata uang dan indeks harga saham diklaim berhubungan dan saling mempengaruhi dimana pelemahan pada salah satu variabel seringkali direspon pula oleh pergerakan pada variabel lainnya. Hubungan dua-arah (kausalitas bivariat) ini dapat dijelaskan oleh model yang menggunakan kaidah dinamis, yaitu model deret waktu. Dalam penelitian ini, nilai tukar Rupiah terhadap Dolar AS dan Indeks Harga Saham Gabungan (IHSG) dianalisis berdasarkan nilai return masing-masing. Data harian dari periode 5 Januari - 24 Mei 2016 sebagai data training digunakan untuk membangun model Autoregressive Moving Average (ARMA) dan Vector Autoregressive (VAR), kemudian dilakukan peramalan selama 10 hari ke depan dan dibandingkan akurasinya. Diindikasikan bahwa model VAR(6) restricted lebih akurat dalam meramalkan return nilai tukar Rupiah, sementara model ARMA $(2,2)$ lebih unggul dalam peramalan return IHSG.
\end{abstract}

Kata Kunci: ARMA, IHSG, kausalitas bivariat, nilai tukar Rupiah, VAR

\begin{abstract}
Currency and stock index in a country are few indicators being considered by businessmen, investor and partner country in drawing necessary decision and action. The exchange rate of currency and stock prices index are supposedly related and influences each other which fall of one variable may be responded by the movement of another variable. Such bivariate causality is able to be explained by dynamic model, namely time series model. In this work, the exchange rate of Rupiah against US Dollar and Jakarta Composite Index (JCI) are analyzed by using their return values. Both daily data ranging from January 5th - May 24th 2016 as training data are considered to construct Autoregressive Moving Average (ARMA) and Vector Autoregressive (VAR) model. Then, the forecasts are conducted for 10 days ahead and the accuracy of both models are compared to determine the best model. It is shown that restricted $\operatorname{VAR}(6)$ is more accurate in forecasting the return of Rupiah exchange rate, while $\operatorname{ARMA}(2,2)$ outclasses VAR in forecasting the return of JCI.
\end{abstract}

Keywords: ARMA, bivariate causality, exchange rate of Rupiah, JCI, VAR

\section{PENDAHULUAN}

Mata uang dan saham merupakan komponen perekonomian yang vital bagi banyak negara. Dua elemen ini seringkali dijadikan acuan untuk mengukur tingkat keberhasilan perekonomian dan iklim investasi. Di Indonesia, mata uang resmi yang digunakan dan diakui oleh pemerintah adalah Rupiah, sementara saham diperdagangkan di Bursa Efek Indonesia. Nilai kurs mata uang dan saham dapat menjadi referensi bagi para pelaku usaha, pebisnis dan investor dalam menentukan langkah dan mengambil keputusan yang dipandang menguntungkan.

Kurs atau dikenal juga sebagai nilai tukar memiliki pengaruh yang cukup besar bagi neraca perdagangan, transaksi berjalan, maupun beberapa variabel makro ekonomi lainnya. Hal ini mengingat peranan nilai tukar yang dapat dijadikan alat untuk mengukur kondisi perekonomian suatu negara (Muchlas dan Alamsyah, 2015). Nilai tukar yang relatif stabil dapat dikatakan mencerminkan pula kondisi perekonomian negara tersebut. Di Indonesia, nilai tukar mata uang asing yang seringkali digunakan sebagai pembanding adalah Dollar AS (\$). Menguatnya nilai tukar Rupiah terhadap Dollar AS dipandang sebagai kondisi yang ideal atau 


\section{Muhammad Luthfi Setiarno Putera}

diharapkan, sementara melemahnya nilai tukar menjadi ancaman dan kekhawatiran bagi pemerintah dan para pebisnis.

Ketidakstabilan nilai tukar Rupiah yang berkepanjangan dapat berdampak negatif kepada indikator perekonomian lainnya, seperti Indeks Harga Saham Gabungan (IHSG). IHSG merupakan salah satu acuan bagi para investor dengan menganalisis pergerakan harga saham, volatilitas dan lain-lain secara global sebelum mengambil keputusan selanjutnya di pasar modal (Rifai, 2019). Buruknya kinerja Rupiah di kancah internasional seringkali diikuti dengan maraknya aksi jual saham oleh para investor asing (non-residen). Namun demikian, pelemahan yang terjadi tidak selalu merugikan karena pelaku usaha dan pebisnis yang berorientasi ekspor akan memperoleh keuntungan yang lebih tinggi (Appa, 2014).

Kasus dalam dunia perekonomian umumnya tidak sederhana layaknya pelemahan nilai tukar yang hanya berdampak kepada penurunan indeks harga saham. Dengan kata lain, kasuskasus perekonomian tidak ditentukan oleh hubungan satu-arah saja. Pada banyak kasus, justru ditemukan hubungan dua-arah atau multi-arah dimana beberapa indikator perekonomian dapat saling mempengaruhi (Wei, 2006; Tsuji, 2015). Artinya, penurunan kinerja pasar modal secara umum juga dapat berdampak kepada nilai tukar dalam kisaran tertentu. Interaksi antara kedua variabel ini juga secara tidak langsung teramati dari minat investor yang tinggi dalam menanamkan modal dalam bentuk saham setelah mengetahui nilai tukar meningkat (Moore dan Wang, 2014; Fauziah, Moeljadi, dan Ratnawati, 2015).

Fenomena hubungan multi-arah ini dapat dijelaskan dengan baik oleh model yang menggunakan kaidah dinamis, yaitu model deret waktu (time series). Dalam ekonomi, perubahan yang terjadi pada satu variabel seringkali dipicu oleh perubahan nilai variabel lainnya pada periode waktu sebelumnya (Inci dan Lee, 2011). Artinya, perubahan yang terjadi tidak spontan atau langsung direspon. Karena melibatkan dua atau lebih variabel, maka terdapat beberapa metode ekonometrik yang dapat digunakan untuk mengidentifikasi variabel yang saling mempengaruhi, salah satunya Vector Autoregressive.

Vector Autoregressive (VAR) adalah metode multivariat yang mampu untuk menjelaskan kausalitas antar variabel secara temporal dan kemudian meramalkan nilai masing-masing variabel untuk jangka waktu tertentu (Wei, 2006; Kumar, Managi, dan Matsuda, 2012). VAR berbeda dengan model Autoregressive (AR) sederhana yang hanya mengkaji data deret waktu secara univariat dengan hanya mempertimbangkan satu variabel saja. Salah satu kajian terdahulu oleh Parsva dan Tang (2017) menemukan bukti bahwa terdapat hubungan kausalitas dua-arah antara indeks harga saham dan nilai tukar di beberapa negara Timur Tengah, yaitu Iran, Oman dan Arab Saudi. Penelitian Tsuji (2015) dan Aladwani (2017) juga mengindikasikan hal serupa dimana nilai tukar dan indeks harga saham saling mempengaruhi untuk mata uang tertentu di Jepang dan Oman.

Penelitian yang mengkaji hubungan kausalitas antara nilai tukar dan indeks harga saham dengan menerapkan perbandingan metode peramalan menggunakan model ekonometrik masih relatif jarang dilakukan di Indonesia. Penelitian ini bertujuan untuk membandingkan akurasi peramalan yang dihasilkan oleh VAR dan ARMA untuk mengetahui efisiensi peramalan. Pemilihan model terbaik ditentukan berdasarkan RMSE dan MAE terendah. Selain itu, pemilihan model juga didasari dari terpenuhinya beberapa asumsi statistik. Peramalan untuk data out-sample (testing) selanjutnya menggunakan metode yang dipandang "terbaik".

\section{LANDASAN TEORI}

\section{Autoregressive Moving Average (ARMA)}

Model Autoregressive Moving Average (ARMA) merupakan model stasioner yang mengkombinasikan dua macam model deret waktu, yaitu model autoregressive (AR) dan model moving average (MA) (Wei, 2006). Model ini dapat direpresentasikan ke dalam persamaan (1), yaitu

$\phi_{p}(B) \dot{Z}_{t}=\theta_{q}(B) a_{t}$,

dengan 
$\phi_{p}(B)=1-\phi_{1} B-\cdots-\phi_{p} B^{p}$, dan $\theta_{q}(B)=1-\theta_{1} B-\cdots-\theta_{q} B^{q}$. Orde $\mathrm{p}$ dan q masing-masing adalah orde AR dan MA. Semakin tinggi orde yang digunakan, baik AR dan MA, maka model yang dihasilkan juga semakin representatif. Namun, efisiensi model menjadi berkurang karena banyaknya parameter yang diestimasi (Gujarati, 2004). Model ARMA pada persamaan (1) umumnya menjadi $\operatorname{ARMA}(p, q)$. Jika orde $p$ memiliki nilai tertentu dengan orde $q$ bernilai 0 , maka model menjadi AR $(p)$. Sebaliknya, jika orde $q$ yang memiliki nilai tertentu dan orde $p$ yang justru bernilai 0, maka model tersebut dikenal sebagai MA(q).

Terdapat beberapa cara untuk menduga orde $p$ dan $q$, salah satunya adalah dengan melalui bantuan visual dari plot Autocorrelation Function (ACF) dan Partial Autocorrelation Function (PACF). Tabel 1 menyajikan kriteria dalam menduga orde $p$ dan $q$ model ARMA berdasarkan pola yang ditunjukkan oleh ACF dan PACF.

Tabel 1. Karakteristik ACF dan PACF untuk Proses Stasioner ARMA

\begin{tabular}{|c|c|c|c|}
\hline & $\mathbf{A R}(p)$ & $\operatorname{MA}(q)$ & $\operatorname{ARMA}(p, q)$ \\
\hline ACF & $\begin{array}{lr}\text { Menurun } & \text { secara } \\
\text { eksponensial } & \text { atau } \\
\text { menyerupai } & \\
\text { gelombang sinus }\end{array}$ & $\begin{array}{l}\text { Cut-off (terpotong) } \\
\text { setelah lag } q\end{array}$ & Menurun setelah lag $(q-p)$ \\
\hline PACF & $\begin{array}{l}\text { Cut-off (terpotong) } \\
\text { setelah lag } p\end{array}$ & $\begin{array}{l}\text { Menurun secara } \\
\text { eksponensial atau } \\
\text { menyerupai } \\
\text { gelombang sinus }\end{array}$ & Menurun setelah lag $(p-q)$ \\
\hline
\end{tabular}

Sumber: Wei, 2006

\section{Vector Autoregressive (VAR)}

Selain regresi deret waktu univariat, dikenal juga beberapa metode yang dapat digunakan untuk menganalisis data deret waktu secara multivariat. Salah satu metode tersebut yaitu Vector Autoregressive (VAR). VAR merupakan penerapan sederhana dari VARMA yang memiliki kemiripan dengan ARMA, yaitu kombinasi dari model AR dan MA, tetapi lebih kompleks karena mempertimbangkan lebih dari 1 variabel dan kausalitas yang terbentuk antar variabel (Gujarati, 2004). Persamaan (2) digunakan untuk merepresentasikan VAR( $p$ ) secara umum,

$$
\boldsymbol{\Phi}_{p}(B) \dot{\mathbf{Z}}_{t}=\mathbf{a}_{t},
$$

dengan $\boldsymbol{\Phi}_{p}(B)=\boldsymbol{\Phi}_{0}-\boldsymbol{\Phi}_{1} B-\boldsymbol{\Phi}_{2} B^{2}-\ldots-\boldsymbol{\Phi}_{p} B^{p}$. Jika terdapat dua variabel yang dianalisis menggunakan VAR(1), maka model dapat dinyatakan ke dalam persamaan (3)

$$
\begin{aligned}
& Z_{1, t}=\phi_{11} Z_{1, t-1}+\phi_{12} Z_{2, t-1}+a_{t} \\
& Z_{2, t}=\phi_{21} Z_{1, t-1}+\phi_{22} Z_{2, t-1}+a_{t}
\end{aligned}
$$

Berdasarkan persamaan (2) dan (3), dapat dikatakan jika VAR memiliki kemiripan dengan sistem persamaan simultan dimana tiap variabel yang dikaji berperan sebagai variabel endogen. Tiap variabel endogen dijelaskan oleh nilai variabel tersebut di periode sebelumnya dan nilai dari variabel lain di periode sebelumnya (Kumar, Managi, dan Matsuda, 2012). Dengan kata lain, terdapat hubungan timbal-balik atau dua-arah antara dua variabel atau lebih pada model VAR.

ACF dan PACF juga ditemui dalam model VARMA yang dapat dinyatakan dalam bentuk matriks, yaitu Matrix Autocorrelation Function (MACF) dan Matrix Partial Autocorrelation Function (MPACF). Berbeda dengan ACF dan PACF, MACF dan MPACF mempertimbangkan hubungan/ korelasi silang antar variabel yang terlibat, tidak hanya pada satu variabel saja seperti pada model ARMA. Untuk pendugaan orde $\operatorname{VAR}(p)$, hampir menyerupai mekanisme pada Tabel 1 untuk model $\mathrm{AR}(p)$, namun pendugaan melalui teknik visual ini seringkali belum sepenuhnya mampu menunjukkan karakteristik MACF dan MPACF secara ideal sesuai dengan teori.

\section{Algoritma Limited-memory BFGS-B}




\section{Muhammad Luthfi Setiarno Putera}

Algoritma L-BFGS-B merupakan ekstensi/pengembangan dari algoritma L-BFGS. Algoritma ini menawarkan kelebihan dibanding pendahulunya dimana algoritma L-BFGS-B lebih fleksibel karena tidak semua fungsi persamaan wajib dibatasi kendala (Zhu, Byrd, dan Nocedal, 1997). Berikut ini merupakan tahapan dari L-BFGS-B per satu kali iterasi:

1) Menghitung taksiran titik Cauchy, yaitu

$$
\Phi(\lambda)=m(\mathbf{x}(\lambda))=m\left(P\left(\mathbf{x}_{k}-\lambda \mathbf{g}_{k}\right)\right) \text {, }
$$

dengan $m(\mathbf{x})$ pada persamaan (4) berbentuk persamaan kuadrat yang dihitung berdasarkan

$$
m(\mathbf{x})=f\left(\mathbf{x}_{k}\right)+\mathbf{g}_{k}^{\mathbf{T}}\left(\mathbf{x}-\mathbf{x}_{k}\right)+\left(\mathbf{x}-\mathbf{x}_{k}\right)^{\mathbf{T}} \mathbf{B}_{k}\left(\mathbf{x}-\mathbf{x}_{k}\right) / 2 .
$$

Pada persamaan (5), $\mathbf{B}_{k}$ adalah matrik Hessian dari $f(\mathbf{x})$ pada iterasi ke- $k$. Tujuannya adalah memperoleh $\mathbf{x}$ yang meminimumkan persamaan (5) sedemikian hingga $\left\|\mathbf{x}-\mathbf{x}_{k}\right\| \leq \Delta$ dimana $\Delta$ merupakan radius dari daerah kepercayaan (trust region).

2) Mengidentifikasi himpunan aktif $A(\mathbf{x})$ dan himpunan in-aktif $I(\mathbf{x})$ dimana $A(\mathbf{x})$ diperoleh berdasarkan metode proyeksi gradien. Proyeksi atas $P$ dilakukan terhadap $\Omega$ untuk $\mathbf{x}$ tertentu hingga tiap $x_{i}$ memiliki

$P\left(x_{i}\right)=\left\{\begin{array}{c}l_{i} \text { jika } x_{i} \leq l_{i}, \\ x_{i} \text { jika } l_{i} \leq x_{i} \leq u_{i}, \\ u_{i} \text { jika } x_{i} \geq u_{i},\end{array}\right.$

dimana $l_{i}$ dan $x_{i}$ merupakan batas atas dan batas bawah yang ditetapkan.

3) Meminimumkan persamaan (5) untuk variabel yang tidak dibatasi oleh kendala.

4) Menerapkan metode pencarian linear untuk memperoleh $f(\mathbf{x})$ yang minimum.

5) Memperbarui matrik Hessian $\mathbf{B}_{k}$ berdasarkan informasi $\mathbf{B}_{0}$ sebanyak $\bar{m}$ kali sehingga diperoleh $\mathbf{B}_{k+1}$ dengan $\widehat{m}=\min (k+1, m)$. Makin tinggi konstanta $m$, maka $\mathbf{B}_{0}$ makin konsisten digunakan untuk memperbarui $\mathbf{B}_{k+1}$. Konstanta $m$ untuk L-BFGS-B biasanya sebesar 5 karena konvergensi pada umumnya tercapai pada titik ini.

6) Menghitung matrik Hessian yang telah diperbarui $\mathbf{B}_{k+1}$ menggunakan persamaan

$$
\mathbf{B}_{k+1}=\mathbf{V}_{k}^{\mathbf{T}} \mathbf{B}_{k} \mathbf{V}_{k}+\rho_{k} \mathbf{s}_{k} \mathbf{s}_{k}^{\mathbf{T}}
$$

dimana

$$
\rho_{k}=\frac{1}{\mathbf{y}_{k}^{\mathbf{T}} \mathbf{s}_{k}} ; \mathbf{V}_{k}=\mathbf{I}-\rho_{k} \mathbf{y}_{k} \mathbf{s}_{k}^{\mathbf{T}} ;\left\{\mathbf{s}_{i}, \mathbf{y}_{i}\right\}=\left\{\mathbf{x}_{i+1}-\mathbf{x}_{i}, \nabla g\left(\mathbf{x}_{i+1}\right)-\nabla g\left(\mathbf{x}_{i}\right)\right\}, i=k-\widehat{m}+1, \ldots, k
$$

7) Persamaan (7) selanjutnya termodifikasi menjadi

$$
\begin{aligned}
\mathbf{B}_{k+1} & =\mathbf{V}_{k}^{\mathbf{T}} \mathbf{B}_{k} \mathbf{V}_{k}+\rho_{k} \mathbf{s}_{k} \mathbf{s}_{k}^{\mathbf{T}}=\mathbf{V}_{k}^{\mathbf{T}}\left(\mathbf{V}_{k-1}^{\mathbf{T}} \mathbf{B}_{k-1} \mathbf{V}_{k-1}+\rho_{k-1} \mathbf{s}_{k-1} \mathbf{s}_{k-1}^{\mathbf{T}}\right) \mathbf{V}_{k}+\rho_{k} \mathbf{s}_{k} \mathbf{s}_{k}^{T} \\
& =\mathbf{V}_{k}^{\mathbf{T}} \mathbf{V}_{k-1}^{\mathbf{T}} \mathbf{B}_{k-1} \mathbf{V}_{k-1} \mathbf{V}_{k}+\rho_{k-1} \mathbf{V}_{k}^{\mathbf{T}} \mathbf{s}_{k-1} \mathbf{s}_{k-1}^{\mathbf{T}} \mathbf{V}_{k}+\rho_{k} \mathbf{s}_{k} \mathbf{s}_{k}^{\mathbf{T}}
\end{aligned}
$$

Karena $\mathbf{B}_{k-1}=\mathbf{V}_{k-2}^{\mathbf{T}} \mathbf{B}_{k-2} \mathbf{V}_{k-2}+\rho_{k-2} \mathbf{s}_{k-2} \mathbf{S}_{k-2}^{\mathbf{T}}$, maka persamaan (8) dapat dinyatakan menjadi

$$
\begin{aligned}
\mathbf{B}_{k+1} & =\mathbf{V}_{k}^{\mathbf{T}} \mathbf{V}_{k-1}^{\mathbf{T}}\left(\mathbf{V}_{k-2}^{\mathbf{T}} \mathbf{B}_{k-2} \mathbf{V}_{k-2}+\rho_{k-2} \mathbf{s}_{k-2} \mathbf{s}_{k-2}^{\mathbf{T}}\right) \mathbf{V}_{k-1} \mathbf{V}_{k}+\rho_{k-1} \mathbf{V}_{k}^{\mathbf{T}} \mathbf{s}_{k-1} \mathbf{s}_{k-1}^{\mathbf{T}} \mathbf{V}_{k}+\rho_{k} \mathbf{s}_{k} \mathbf{s}_{k}^{T} \\
& =\mathbf{V}_{k}^{\mathbf{T}} \mathbf{V}_{k-1}^{\mathbf{T}} \mathbf{V}_{k-2}^{\mathbf{T}} \mathbf{B}_{k-2} \mathbf{V}_{k-2} \mathbf{V}_{k-1} \mathbf{V}_{k}+\rho_{k-1} \mathbf{V}_{k}^{\mathbf{T}} \mathbf{V}_{k-1}^{\mathbf{T}} \mathbf{s}_{k-2} \mathbf{s}_{k-2}^{\mathbf{T}} \mathbf{V}_{k-1} \mathbf{V}_{k}+\rho_{k-1} \mathbf{V}_{k}^{\mathbf{T}} \mathbf{s}_{k-1} \mathbf{s}_{k-1}^{\mathbf{T}} \mathbf{V}_{k}+\rho_{k} \mathbf{s}_{k} \mathbf{s}_{k}^{\mathbf{T}}
\end{aligned}
$$

8) Berdasarkan persamaan (7), (8) dan (9), maka diperoleh persamaan umum untuk menghitung matrik Hessian yang diperbarui $\mathbf{B}_{k+1}$

$$
\begin{aligned}
\mathbf{B}_{k+1}= & \left(\mathbf{V}_{k}^{\mathbf{T}} \mathbf{V}_{k-1}^{\mathbf{T}} \ldots \mathbf{V}_{k-\hat{m}+1}^{\mathbf{T}}\right) \mathbf{B}_{k-\hat{m}+1}\left(\mathbf{V}_{k-\hat{m}+1} \ldots \mathbf{V}_{k-1} \mathbf{V}_{k}\right)+\rho_{k-\hat{m}+1}\left(\mathbf{V}_{k-1}^{\mathbf{T}} \mathbf{V}_{k-2}^{\mathbf{T}} \ldots \mathbf{V}_{k-\hat{m}+2}^{\mathbf{T}}\right) \mathbf{s}_{k-\hat{m}+1} \mathbf{s}_{k-\hat{m}+1}^{\mathbf{T}}\left(\mathbf{V}_{k-\hat{m}+2} \ldots \mathbf{V}_{k-2} \mathbf{V}_{k-1}\right)+\ldots+ \\
& \rho_{k-1} \mathbf{V}_{k}^{\mathbf{T}} \mathbf{s}_{k-1} \mathbf{s}_{k-1}^{\mathbf{T}} \mathbf{V}_{k}+\rho_{k} \mathbf{s}_{k} \mathbf{s}_{k}^{\mathbf{T}}
\end{aligned}
$$


9) Kembali ke langkah 1 dan selanjutnya mengulangi tahapan iterasi untuk $\mathrm{k}+1$ hingga konvergensi tercapai dengan kriteria $\left\|\mathbf{g}_{k+1}-\mathbf{g}_{k}\right\|<\varepsilon$ dengan $\varepsilon$ merupakan bilangan yang sangat kecil.

\section{DATA DAN METODE}

Data yang digunakan dalam penelitian ini adalah data deret waktu nilai return nilai tukar Rupiah terhadap Dollar AS (US \$) dan nilai return Indeks Harga Saham Gabungan (IHSG). Metode penghitungan nilai return pada penelitian ini menggunakan persamaan (11)

$$
\text { return } \mathrm{IHSG}_{t}=\frac{I H S G_{t}-I H S G_{t-1}}{I H S G_{t-1}}
$$

dengan IHSG $_{\mathrm{t}}$ merupakan nilai IHSG pada saat penutupan di hari ke- $t$ dan IHSG $_{\mathrm{t}-1}$ merupakan nilai IHSG pada saat penutupan di hari ke- $t$ - 1 atau tepat 1 hari sebelumnya. Penggunaan nilai return lebih dipilih karena dapat menghindari differencing atas data deret waktu yang menyebabkan transformasi hasil peramalan menjadi semakin kompleks.

Data nilai tukar Rupiah terhadap Dollar AS (US \$), dapat dinyatakan sebagai $Z_{1}$, diperoleh dari Bank Indonesia melalui laman web www.bi.go.id/id/moneter/informasi-kurs/referensi-jisdor. Data IHSG, dinyatakan sebagai $Z_{2}$, diperoleh dari laman Yahoo Finance. Data yang digunakan dalam penelitian ini dimulai dari 5 Januari 2016 hingga 7 Juni 2016. Data training yang digunakan untuk membentuk model adalah data pada 5 Januari 2016 - 24 Mei 2016 (96 hari transaksi), sedangkan periode data testing yang digunakan untuk mengetahui akurasi peramalan dimulai pada 25 Mei 2016 - 7 Juni 2016 (10 hari transaksi). Dua variabel dimodelkan dengan ARMA dan VAR dimana akurasi hasil ramalan dibandingkan dengan menggunakan indikator Root Mean Square Error (RMSE) dan Mean Absolute Error (MAE).

\section{HASIL DAN PEMBAHASAN}

\section{Analisis Data Eksploratori}

Dalam statistika, analisis data eksploratori dapat memberikan gambaran awal mengenai karakteristik data penelitian. Karakteristik yang dimaksud adalah seperti adanya keberadaan pencilan (outlier), sebaran / distribusi data, data missing, dan sebagainya. Tidak semua data memiliki karakteristik yang serupa. Perbedaan tersebut biasanya turut menentukan seberapa tepat dan layak data tersebut dianalisis dengan menggunakan metode atau pemodelan secara statistik. Gambar 1 menyajikan tren nilai return nilai tukar Rupiah dan nilai return IHSG.

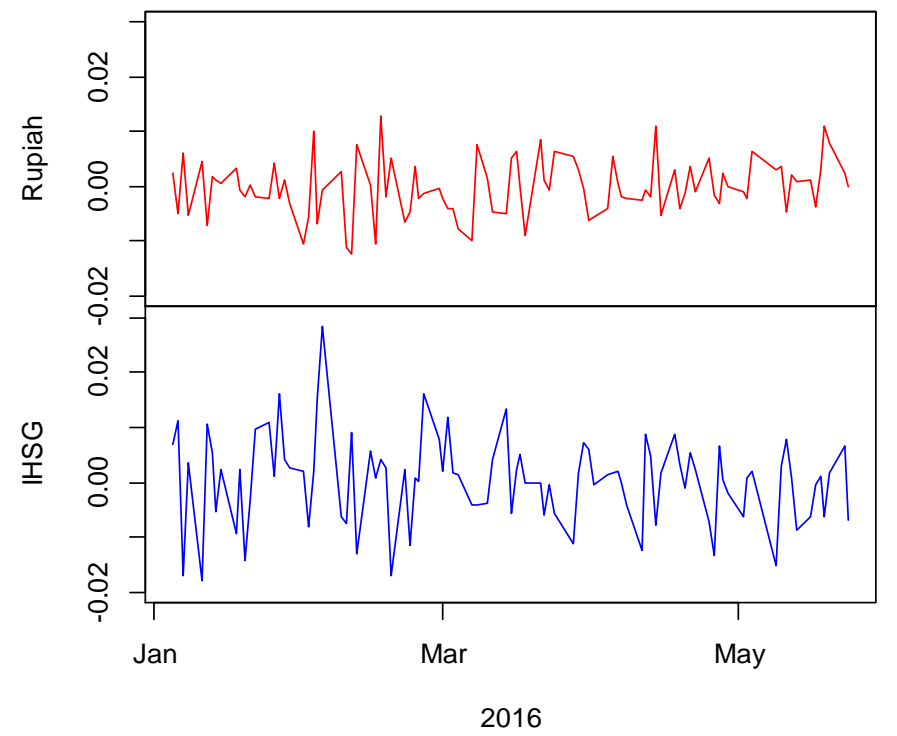

Gambar 1. Grafik deret waktu return nilai tukar Rupiah dan return IHSG 


\section{Muhammad Luthfi Setiarno Putera}

Dari Gambar 1, terlihat bahwa masing-masing variabel menunjukkan pola yang fluktuatif dimana hal ini lazim ditemukan pada data yang berhubungan dengan perekonomian, bisnis dan investasi yang selalu mengalami perubahan akibat pengaruh dari faktor internal dan eksternal. Terdapat indikasi bahwa data telah stasioner dalam mean dan varians karena tidak menunjukkan gejala adanya kemunculan titik pengamatan yang letaknya jauh menyimpang dari pengamatan-pengamatan lainnya.

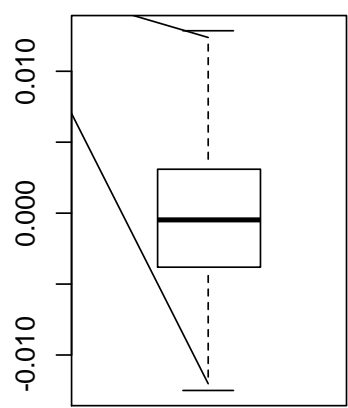

(a) Rupiah

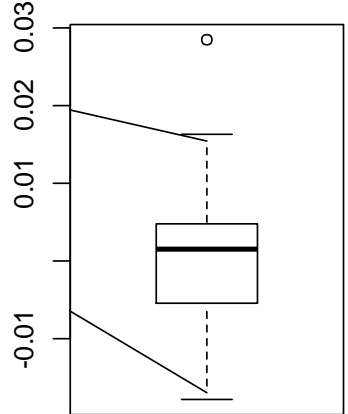

(b) IHSG

Gambar 2. Box plot return nilai tukar Rupiah dan return IHSG

Berdasarkan Gambar 2, sebaran data menunjukkan bahwa dua variabel memiliki kemiripan dengan distribusi normal, terutama pada variabel return nilai tukar Rupiah. Hal yang menarik adalah adanya keberadaan satu titik ekstrem pada variabel return IHSG. Titik ekstrem ini yang diperkirakan menyebabkan rata-rata bergeser menjadi melebihi 0 , namun demikian tidak bisa dikatakan apakah titik ini adalah outlier atau bukan sebelum dilakukan pengujian. Pada model deret waktu, keberadaan titik ekstrem biasanya tidak menyebabkan model menjadi gagal diestimasi sepanjang jumlahnya tidak melebihi rasio tertentu.

\section{Model ARMA untuk Return Nilai Tukar Rupiah dan IHSG}

Sebelum memulai estimasi dengan model ARMA, tahapan yang dilakukan adalah menguji stasioneritas return nilai tukar Rupiah dan return IHSG. Jika data tidak stasioner dan penanganan yang dilakukan keliru, maka analisis dan pengujian akan berdampak pada penarikan inferensi yang kurang tepat. Jika data tidak stasioner, maka perlu ditelaah pada orde differencing $d$ berapa stasioneritas data tercapai.

Dengan menggunakan uji akar unit ADF, diperoleh p-value masing-masing sebesar 0,01 untuk kedua data. Hal ini mengindikasikan data return nilai tukar Rupiah dan return IHSG telah stasioner dan tidak memerlukan differencing. Selanjutnya, menduga orde $p$ dan $q$ untuk model ARMA melalui plot ACF dan PACF seperti yang ditampilkan pada Gambar 3.

Selain digunakan untuk menduga orde model ARMA, plot ACF biasanya juga dapat digunakan untuk melihat stasioneritas data. Berdasarkan Gambar 3, dapat dikatakan bahwa uji ADF dan pola pada plot ACF menunjukkan hasil yang sama dimana kedua data sudah stasioner. Gambar 3 juga mengindikasikan bahwa orde $p$ dan $q$ untuk return nilai tukar Rupiah relatif kompleks untuk teridentifikasi. Sementara, kendala serupa juga ditemui pada return IHSG. Namun demikian, return IHSG masih menunjukkan adanya ACF dan PACF yang signifikan pada lag ke-6 dan ke-7. Hal ini mengindikasikan bahwa return IHSG kemungkinan memiliki perilaku serupa dengan model ARMA.

Adanya kendala dalam menentukan orde $p$ dan $q$ melalui ACF dan PACF mendorong munculnya pemilihan model ARMA dengan menggunakan kriteria AIC yang terendah. Tabel 2 menampilkan AIC beberapa model yang dipertimbangkan untuk dua variabel. 

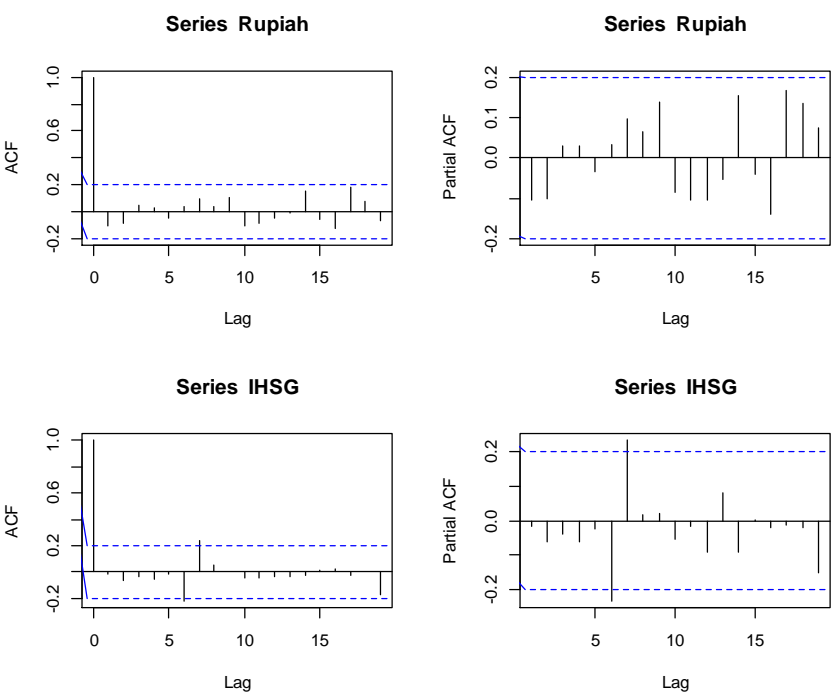

Gambar 3. ACF dan PACF return nilai tukar Rupiah dan return IHSG

Tabe1 2. Nilai AIC Alternatif Model ARMA

\begin{tabular}{|l|c|c|}
\hline \multicolumn{1}{|c|}{ Model } & Return Nilai Tukar Rupiah & Return IHSG \\
\hline AR(1) & $-734,34$ & $-648,91$ \\
\hline MA(1) & $-734,57^{*}$ & $-648,91$ \\
\hline ARMA(1,1) & $-732,66$ & $-647,67$ \\
\hline ARMA(2,2) & Tak berhingga & $-650,22^{*}$ \\
\hline
\end{tabular}

Ket. * merupakan model dengan AIC terendah

Pada Tabel 2, diperoleh AIC untuk beberapa alternatif model yang merepresentasikan return nilai tukar Rupiah dan return IHSG. Diperoleh bahwa model ARMA yang dianggap lebih baik adalah MA(1) untuk return nilai tukar Rupiah dan $\operatorname{ARMA}(2,2)$ untuk return IHSG. Selanjutnya, mengestimasi parameter model deret waktu untuk dua variabel tersebut agar memperoleh persamaan yang digunakan dalam peramalan terhadap data testing.

Estimasi parameter pada model deret waktu dapat menggunakan berbagai teknik, seperti maximum likelihood, kuadrat terkecil (least squares) atau iteratif menggunakan algoritma tertentu. Pada penelitian ini, seperti diuraikan pada bab sebelumnya, estimasi dilakukan secara iteratif menggunakan algoritma L-BFGS-B. Penggunaan teknik ini biasanya memberikan hasil estimasi yang lebih efisien, terutama pada data berdimensi tinggi.

Tabel 3. Estimasi dan Signifikansi Parameter Model ARMA

\begin{tabular}{l|l|c|c|c|c|}
$\begin{array}{l}\text { Return nilai } \\
\text { tukar } \\
\text { Rupiah } \\
\text { MA(1) }\end{array}$ & Parameter & Estimasi & s.e. & z-hitung & p-value \\
\cline { 2 - 6 } & Konstanta & $-0,0002$ & 0,0005 & $-0,4511$ & 0,6519 \\
\cline { 2 - 6 } & MA(1) & $-0,1237$ & 0,1088 & $-1,1376$ & 0,2553 \\
\cline { 2 - 6 } & Parameter & Estimasi & s.e. & z-hitung & p-value \\
\cline { 2 - 6 } & Konstanta & 0,0004 & 0,0008 & 0,5622 & 0,574 \\
\cline { 2 - 6 } $\begin{array}{l}\text { Return } \\
\text { IHSG } \\
\text { ARMA(2,2) }\end{array}$ & AR(1) & $-1,6697$ & 0,1748 & $-9,552$ & $<0,001^{*}$ \\
\cline { 2 - 6 } & $\mathrm{AR}(2)$ & $-0,7689$ & 0,1389 & $-5,5332$ & $<0,001^{*}$ \\
\cline { 2 - 6 } & $\mathrm{MA}(1)$ & 1,7188 & 0,2022 & 8,5016 & $<0,001^{*}$ \\
\cline { 2 - 6 } & $\mathrm{MA}(2)$ & 0,7493 & 3,9478 & $<0,001^{*}$ \\
\hline
\end{tabular}

Ket. * signifikan pada $a=5 \%$ 


\section{Muhammad Luthfi Setiarno Putera}

Tabel 3 menunjukkan bahwa parameter model MA(1) untuk return nilai tukar Rupiah seluruhnya tidak signifikan, meski memiliki nilai AIC terendah dari beberapa kandidat model. Sedangkan parameter model ARMA $(2,2)$ untuk return IHSG hampir seluruhnya signifikan pada $\mathrm{a}=5 \%$, kecuali konstanta. Artinya, model ARMA $(2,2)$ tepat dalam mewakili perilaku variabel return IHSG. Sementara, model MA(1) untuk return nilai tukar Rupiah tidak mampu mewakili perilaku variabel dengan cukup baik menurut kaidah deret waktu. Namun demikian, model MA(1) akan tetap digunakan dan dibandingkan dengan model VAR untuk return nilai tukar Rupiah.

\section{Model VAR untuk Return Nilai Tukar Rupiah dan IHSG}

Untuk membuktikan adanya hubungan kausalitas antara return nilai tukar Rupiah dan return IHSG, maka diperlukan analisis melalui model VAR. Sebelum mengestimasi parameter, langkah serupa dilakukan seperti halnya pada model AR, yaitu dengan mengidentifikasi MACF dan MPACF untuk menduga orde $p$ pada model VAR. Gambar 4 menyajikan plot MACF dan MPACF untuk return nilai tukar Rupiah dan return IHSG.

Rupiah

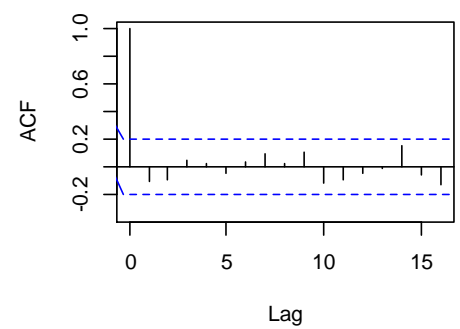

IHSG \& Rupiah

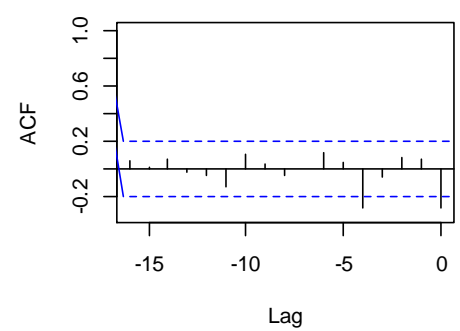

Rupiah \& IHSG

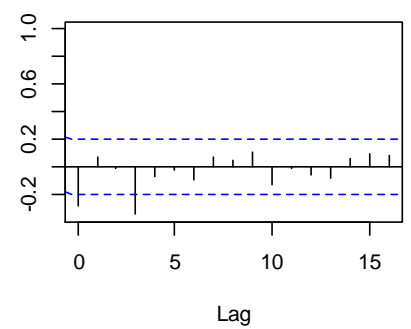

IHSG

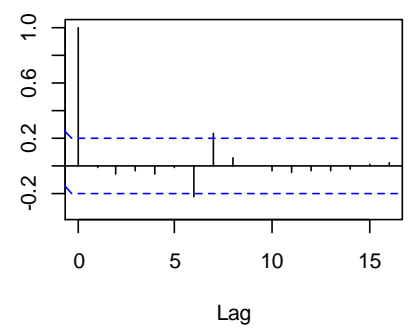

MACF return nilai tukar Rupiah dan return IHSG 
Rupiah

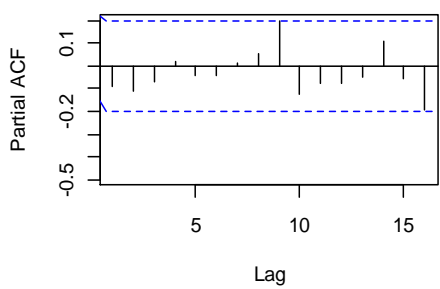

IHSG \& Rupiah

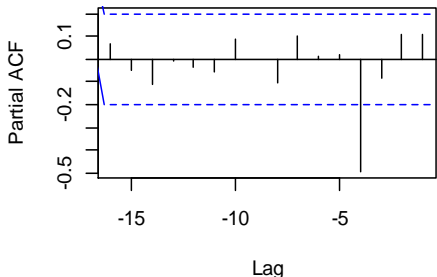

Rupiah \& IHSG

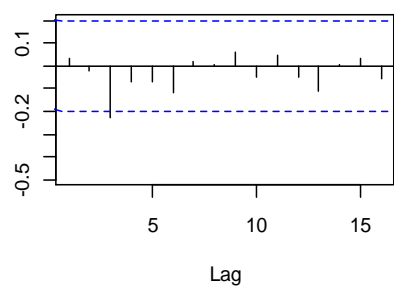

IHSG

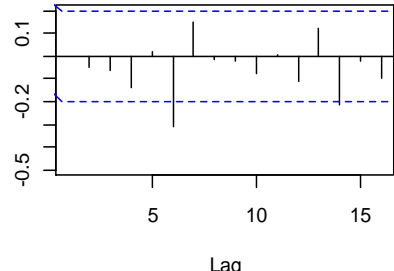

Lag

MPACF return nilai tukar Rupiah dan return IHSG

Gambar 4. MACF dan MPACF Variabel Makroekonomi

Berdasarkan Gambar 4, terlihat bahwa tidak terdapat perbedaan ACF pada return nilai tukar Rupiah dan return IHSG karena merupakan replikasi dari Gambar 3 (perhatikan plot pada Gambar 4 di sebelah pojok kanan atas dan pojok kiri bawah). Perbedaan substansial adalah pada hadirnya plot korelasi silang (cross-correlation function/CCF) antara dua variabel tersebut. Berdasarkan plot CCF pada Gambar 4, diduga terdapat hubungan dua-arah antara return nilai tukar Rupiah dan return IHSG, meski hubungan yang terjadi tidak serta-merta direspon dalam waktu yang singkat, ada jeda yang relatif panjang dalam merespon perubahan yang terjadi, baik pada variabel return nilai tukar Rupiah maupun return IHSG.

Setelah menganalisis MACF dan MPACF, berikutnya adalah menentukan orde $p$ yang optimal untuk model VAR berdasarkan kriteria AIC yang terkecil. Tabel 4 menyajikan ringkasan AIC model VAR untuk $p=1$ hingga $p=10$.

Tabel 4. Ringkasan AIC untuk Kandidat Model VAR

\begin{tabular}{|l|c|c|c|c|c|}
\hline VAR(p) & 1 & 2 & 3 & 4 & 5 \\
\hline AIC & $-20,17$ & $-20,12$ & $-20,25$ & $-20,30$ & $-20,23$ \\
\hline VAR(p) & 6 & 7 & 8 & 9 & 10 \\
\hline AIC & $-20,37^{*}$ & $-20,31$ & $-20,23$ & $-20,19$ & $-20,13$ \\
\hline
\end{tabular}

Tabel 4 menunjukkan bahwa orde $p$ yang dipandang paling efisien untuk digunakan model VAR pada kasus ini adalah 6. Artinya, terdapat kecenderungan bahwa pengaruh variabel lainnya dirasakan variabel tertentu hingga 6 hari sebelumnya.

Estimasi parameter model VAR termasuk bagian yang esensial karena menjadi pembuktian signifikansi kausalitas antara dua variabel dalam penelitian ini. Namun, untuk memberikan keyakinan adanya hubungan dua-arah (feedback relationship), dilakukan uji Granger dengan hasil seperti ditampilkan pada Tabel 5.

Tabel 5. Ringkasan AIC untuk Kandidat Model VAR

\begin{tabular}{|l|c|c|}
\hline & F-hitung & p-value \\
\hline Rupiah mempengaruhi IHSG & 2,86 & $0,014^{*}$ \\
\hline IHSG mempengaruhi rupiah & 3,28 & $0,001^{*}$ \\
\hline
\end{tabular}

Ket. * signifikan pada $a=5 \%$ dengan d.b numerator $=77$, d.b renumerator $=83$ 


\section{Muhammad Luthfi Setiarno Putera}

Tabel 5 menunjukkan bahwa dua variabel secara statistik telah memenuhi unsur kausalitas / hubungan dua-arah. Oleh karena itu, langkah selanjutnya adalah mengestimasi parameter model VAR(6) seperti yang diindikasikan oleh Tabel 4.

Persamaan umum yang berlaku untuk return nilai tukar Rupiah dan IHSG yang dimodelkan dengan VAR(6) adalah

$$
\begin{aligned}
& Z_{1, t}=Z_{1, t-1}+\cdots+Z_{1, t-6}+Z_{2, t-1}+\cdots+Z_{2, t-6} \\
& Z_{2, t}=Z_{1, t-1}+\cdots+Z_{1, t-6}+Z_{2, t-1}+\cdots+Z_{2, t-6},
\end{aligned}
$$

dengan $Z_{1, t}$ dan $Z_{2, t}$ masing-masing adalah return nilai tukar Rupiah dan return IHSG pada hari ke-t. Estimasi parameter model VAR(6) beserta signifikansinya disajikan pada Tabel 6.

Tabel 6. Estimasi Parameter Model VAR(6)

\begin{tabular}{|c|c|c|c|c|c|c|c|}
\hline \multicolumn{4}{|c|}{ Rupiah } & \multicolumn{4}{c|}{ IHSG } \\
\hline $\begin{array}{c}\text { Para- } \\
\text { meter }\end{array}$ & Estimasi & $\begin{array}{c}\text { Parame- } \\
\text { ter }\end{array}$ & Estimasi & $\begin{array}{c}\text { Para- } \\
\text { meter }\end{array}$ & $\begin{array}{c}\text { Estimas } \\
\text { i }\end{array}$ & $\begin{array}{c}\text { Parame- } \\
\text { ter }\end{array}$ & Estimasi \\
\hline $\mathrm{Rp}(-1)$ & $-0,143$ & IHSG(-1) & $-0,051$ & $\mathrm{Rp}(-1)$ & $-0,099$ & IHSG(-1) & 0,052 \\
\hline $\mathrm{Rp}(-2)$ & $-0,196$ & IHSG(-2) & $-0,027$ & $\mathrm{Rp}(-2)$ & 0,022 & IHSG(-2) & $-0,103$ \\
\hline $\mathrm{Rp}(-3)$ & $-0,126$ & IHSG(-3) & $-0,291^{*}$ & $\mathrm{Rp}(-3)$ & $-0,450^{*}$ & IHSG(-3) & $-0,055$ \\
\hline $\mathrm{Rp}(-4)$ & $-0,037$ & IHSG(-4) & $-0,072$ & $\mathrm{Rp}(-4)$ & $-0,561^{*}$ & IHSG(-4) & $-0,174$ \\
\hline $\mathrm{Rp}(-5)$ & $-0,049$ & IHSG(-5) & $-0,075$ & $\mathrm{Rp}(-5)$ & $-0,009$ & IHSG(-5) & $-0,007$ \\
\hline $\mathrm{Rp}(-6)$ & $-0,029$ & IHSG(-6) & $-0,119$ & $\mathrm{Rp}(-6)$ & $-0,042$ & IHSG(-6) & $-0,352^{*}$ \\
\hline
\end{tabular}

Ket. * signifikan pada $a=5 \%$

Tabel 6 menunjukkan bahwa tidak seluruh parameter memiliki pengaruh yang berbeda nyata terhadap masing-masing variabel. Model VAR(6) untuk return nilai tukar Rupiah hanya terdapat satu parameter signifikan, yaitu IHSG $_{t-3}$. Untuk return IHSG, parameter yang signifikan lebih banyak, yaitu $\mathrm{Rp}_{t-3}, \mathrm{Rp}_{t-4}$ dan $\mathrm{IHSG}_{t-6}$. Koefisien determinasi VAR untuk return nilai tukar dan IHSG masing-masing sebesar 22,77\% dan 25,73\%. Mengingat banyaknya parameter yang tidak signifikan, maka dilakukan proses restrict atau pemodelan ulang dengan hanya melibatkan parameter yang signifikan saja sesuai dengan hasil pada Tabel 6.

Pemodelan ulang dengan konsep restrict menyebabkan model VAR hanya didasari pada parameter yang saja. Hasil estimasi parameter tersebut dapat dilihat pada Tabel 7.

Tabel 7. Estimasi Parameter Model VAR(6) setelah Restrict

\begin{tabular}{|l|c|c|c|}
\hline \multicolumn{1}{|c|}{ Rupiah } & Estimasi & s.e & p-value \\
\hline IHSG(-3) & $-0,266$ & 0,063 & $<0,0001$ \\
\hline & R-sq $=16,53 \%$ & \multicolumn{2}{|c|}{ p-value kebaikan model $=<0,0001$} \\
\hline \multicolumn{1}{|c|}{ IHSG } & Estimasi & s.e & p-value \\
\hline Rp(-3) & $-0,407$ & 0,152 & 0,009 \\
\hline Rp(-4) & $-0,504$ & 0,145 & 0,001 \\
\hline IHSG(-6) & $-0,318$ & 0,095 & 0,001 \\
\hline & R-sq $=21,09 \%$ & p-value kebaikan model $=<0,0005$ \\
\hline
\end{tabular}

Setelah mengalami restrict, diperoleh model VAR yang lebih ringkas karena hanya terdiri dari parameter yang signifikan pada $\mathrm{a}=5 \%$. Berikut ini merupakan persamaan yang merepresentasikan model VAR yang akan digunakan untuk meramalkan return nilai tukar Rupiah dan return IHSG. 
$Z_{1, t}=-0,266 Z_{2, t-3}+a_{1, t}$

$z_{2, t}=-0,407 Z_{1, t-3}-0,504 Z_{1, t-4}-0,318 z_{2, t-6}+a_{2 t}$

Residual atau galat data training dari persamaan (6) kemudian akan terlebih dahulu menjalani diagnostic checking untuk memastikan seluruh asumsi statistik terpenuhi.

\section{Pemeriksaan Asumsi (Diagnostic Checking)}

Pemeriksaan asumsi residual dimulai dengan menganalisis plot ACF residual. Hal ini bertujuan untuk memastikan residual model ARMA yang diperoleh untuk return nilai tukar Rupiah dan return IHSG memenuhi asumsi independen. Plot ACF residual model ARMA disajikan pada Gambar 5.
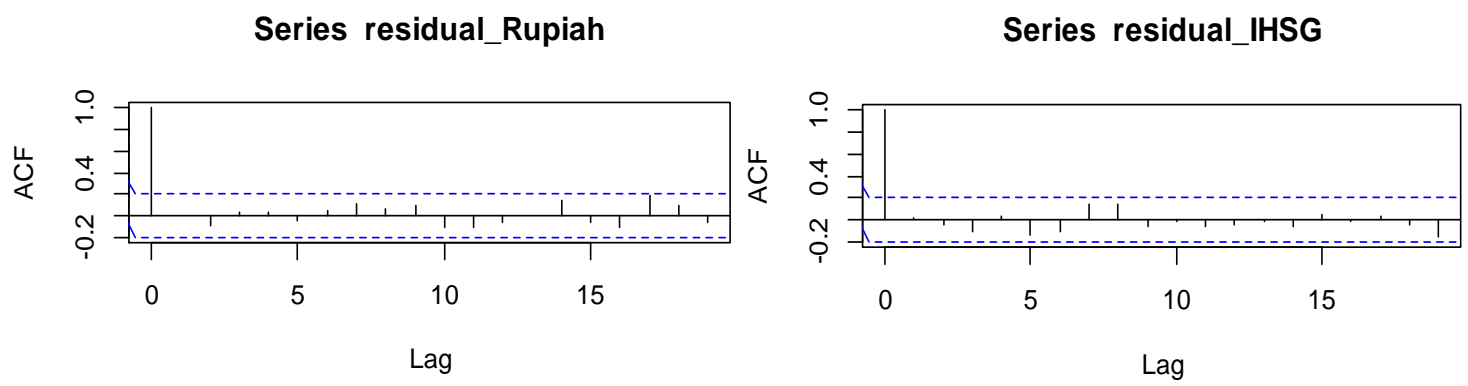

Gambar 5. ACF residual model ARMA

Berdasarkan Gambar 5, residual model telah memenuhi asumsi independen (tidak terindikasi otokorelasi) karena tidak ditemukan ACF yang melewati batas signifikansi (ditunjukkan oleh garis putus-putus). Kemudian, Tabel 8 memberikan ringkasan mengenai hasil pengujian signifikansi pelanggaran heteroskedastisitas dan normalitas residual.

Tabe1 8. Uji asumsi residual model ARMA

\begin{tabular}{|l|c|c|}
\hline & $\begin{array}{c}\text { p-value MA(1) return } \\
\text { nilai tukar Rupiah }\end{array}$ & $\begin{array}{c}\text { p-value ARMA(2,2) } \\
\text { return IHSG }\end{array}$ \\
\hline Uji Lagrange multiplier (LM) & 0,079 & 0,365 \\
\hline Uji normalitas Shapiro-Wilk & 0,915 & 0,228 \\
\hline
\end{tabular}

Tabel 8 menunjukkan bahwa residual kedua model, baik MA(1) untuk Rupiah dan ARMA(2,2) untuk IHSG, telah memenuhi asumsi homoskedastisitas dan normalitas. Hal ini terlihat dari $p$ value masing-masing uji yang bernilai lebih dari $a=5 \%$. Artinya, residual model ARMA dari return nilai tukar Rupiah dan return IHSG telah memenuhi asumsi white noise dan kedua model dianggap sudah mampu merepresentasikan data.

Selanjutnya, memeriksa pemenuhan asumsi residual dari model VAR yang sudah diperoleh sebelumnya yang direpresentasikan oleh persamaan (6). Langkah yang serupa dengan model ARMA diterapkan, yaitu dengan mengidentifikasi plot MACF residual model VAR. Gambar 6 menyajikan plot MACF residual model VAR(6) yang sudah di-restrict. 


\section{Muhammad Luthfi Setiarno Putera}

Rupiah

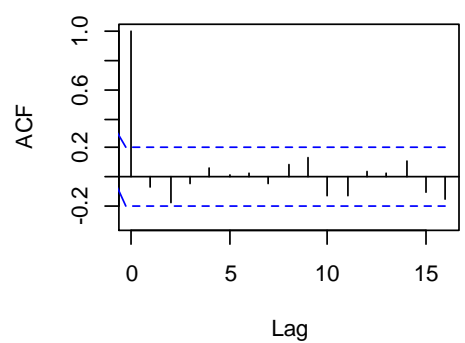

IHSG \& Rupiah

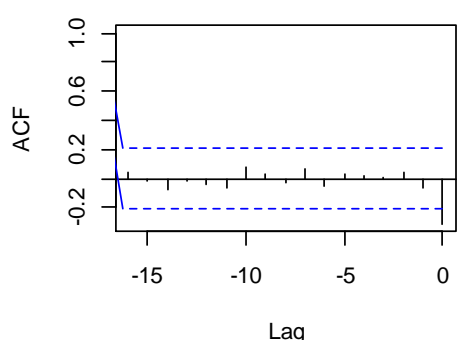

Rupiah \& IHSG

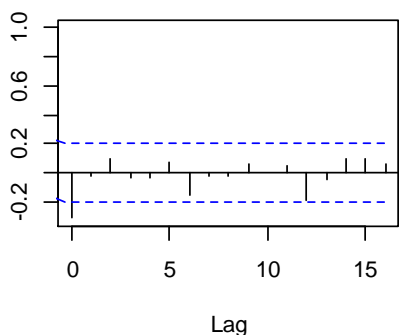

IHSG

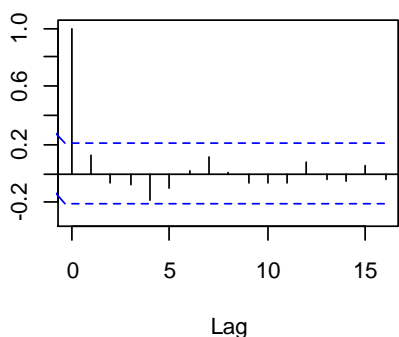

Gambar 6. MACF residual model VAR

Gambar 6 menunjukkan bahwa residual model VAR telah memenuhi asumsi independen (tidak terindikasi otokorelasi). Dari Gambar 6, tidak ditemukan ACF dan CCF yang melewati batas signifikansi (ditunjukkan oleh garis putus-putus). Tabel 9 menyajikan ringkasan mengenai hasil uji signifikansi pelanggaran heteroskedastisitas dan normalitas residual.

Tabel 9. Uji asumsi residual model VAR

\begin{tabular}{|l|c|l|c|}
\hline \multicolumn{1}{|c|}{ Uji statistik } & p-value & Uji statistik & p-value \\
\hline Uji Portmanteau & 0,112 & Uji normalitas univariat (Rupiah) & 0,372 \\
\hline Uji Lagrange multiplier (LM) & 0,915 & Uji normalitas univariat (IHSG) & 0,232 \\
\hline Uji normalitas multivariat & 0,434 & \multicolumn{2}{|l}{} \\
\cline { 1 - 3 } & \multicolumn{2}{|c|}{} &
\end{tabular}

Berdasarkan Tabel 9, seluruh asumsi yang disyaratkan untuk dipenuhi residual model VAR tidak terlanggar. Sehingga, model VAR(6) dengan restrict dipandang layak dan mampu merepresentasikan perilaku variabel penelitian secara multivariat. Selanjutnya, melakukan peramalan (forecast) untuk masing-masing variabel dengan menggunakan model ARMA dan juga VAR.

\section{Peramalan}

Tahap ini merupakan tahap akhir dimana peramalan dilakukan untuk beberapa periode waktu ke depan. Dalam kasus ini, diketahui bahwa data training berakhir pada tanggal 24 Mei 2016. Artinya, titik asal (origin) bermula pada tanggal tersebut. Karena periode data testing dimulai dari 25 Mei 2016 hingga 9 hari kerja berikutnya, maka lead untuk dicapai adalah selama 10 hari. Gambar 7 menyajikan perbandingan antara nilai aktual dan nilai ramalan dari dua variabel dengan menggunakan model ARMA (regresi deret waktu univariat). 

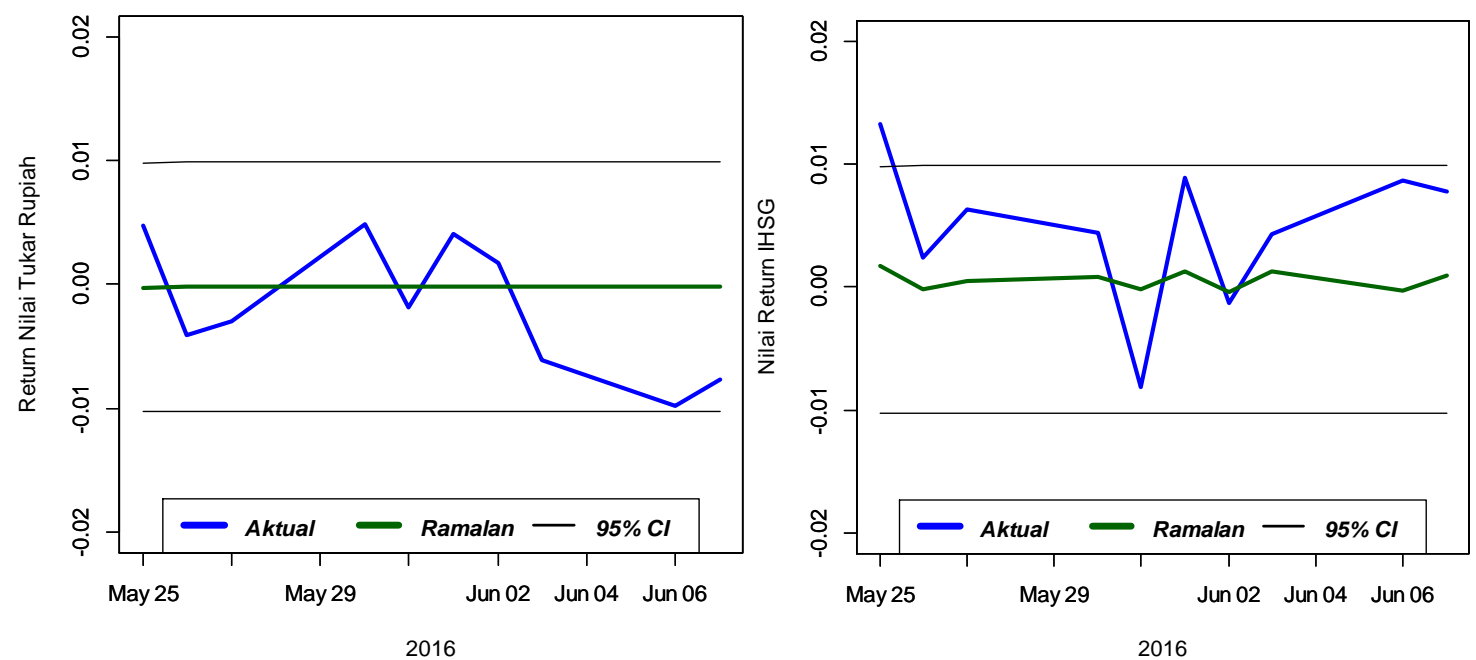

Gambar 7. Peramalan dengan Model ARMA

Berdasarkan Gambar 7, diindikasikan bahwa model ARMA menunjukkan kemampuan yang cukup akurat dalam meramalkan dua variabel, terutama return IHSG. Hal ini disebabkan model ARMA(2,2) memberikan hasil yang mampu mengikuti dinamika pergerakan return IHSG meski di hari pertama peramalan nilai aktual justru berada di luar selang kepercayaan 95\%. Kekurangan model ARMA justru ditunjukkan oleh model MA(1) yang relatif monoton, terlepas dari adanya pergerakan return nilai tukar yang fluktuatif.
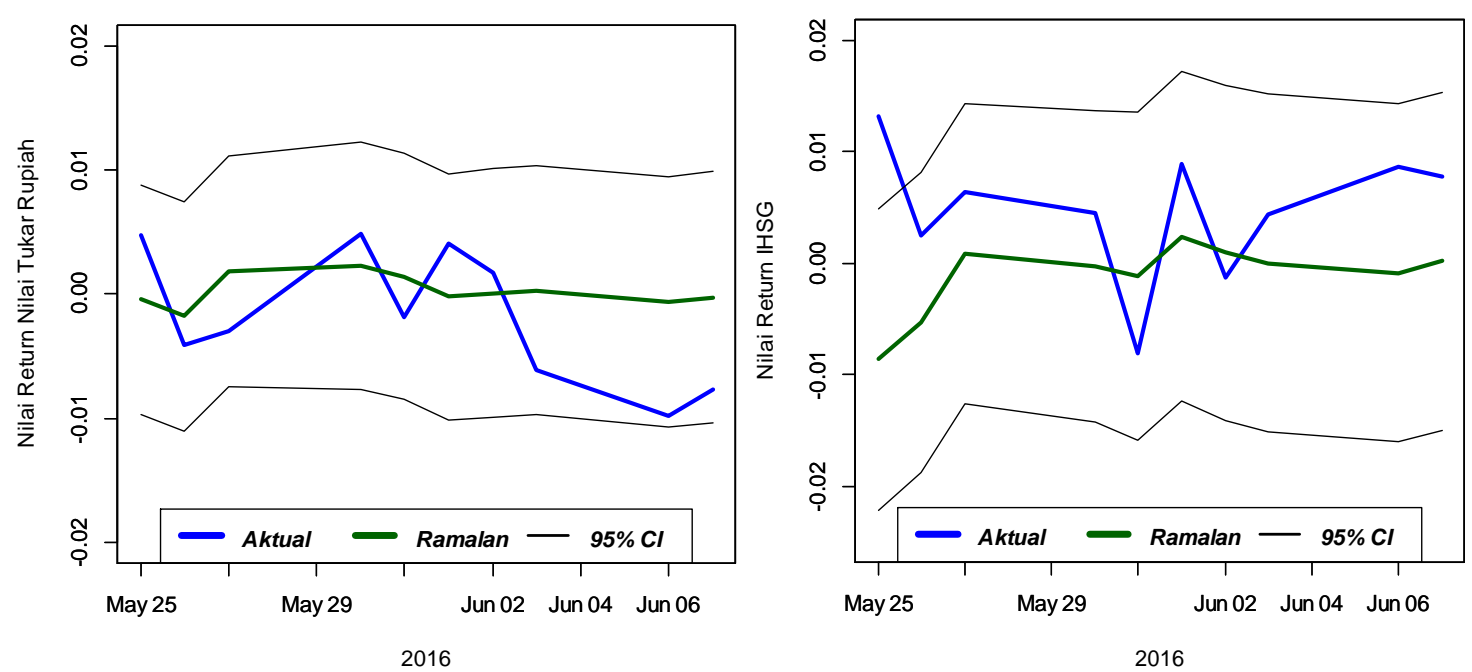

Gambar 8. Peramalan dengan Model VAR

Gambar 8 mengindikasikan adanya perkembangan dengan model VAR terlihat mampu menghasilkan ramalan yang mendekati nilai aktual, terutama pada 6-7 hari awal, baik untuk return nilai tukar dan return IHSG. Meski demikian, inakurasi model VAR dalam memprediksi untuk jangka menengah dan panjang mulai terlihat di akhir periode data testing dimana jarak antara nilai aktual dan ramalan melebar. Kelebihan lain dari model VAR adalah selang kepercayaan yang adaptif mengikuti nilai ramalan. Sebagai indikator lainnya dalam menentukan model "terbaik", digunakan RMSE dan MAE dimana model yang terpilih memiliki nilai RMSE dan MAE yang terkecil. 


\section{Muhammad Luthfi Setiarno Putera}

Tabel 10. Uji asumsi residual model VAR

\begin{tabular}{|l|c|c|c|c|}
\hline \multirow{2}{*}{ Indikator } & \multicolumn{2}{|c|}{ Rupiah } & \multicolumn{2}{c|}{ IHSG } \\
\cline { 2 - 5 } & MA(1) & VAR & ARMA(2,2) & VAR \\
\hline RMSE & 0,0053 & 0,0052 & 0,0052 & 0,0092 \\
\hline MAE & 0,0048 & 0,0047 & 0,0047 & 0,0077 \\
\hline
\end{tabular}

Tabel 10 mengindikasikan bahwa VAR lebih akurat dalam meramalkan return nilai tukar Rupiah, sedangkan ARMA $(2,2)$ lebih menonjol dari segi akurasi dalam peramalan return IHSG. Pada variabel return IHSG, akurasi VAR jauh menurun dibanding ARMA karena kegagalan ramalan model VAR dalam mendekati nilai aktual pada hari pertama data testing. Artinya, model yang lebih sederhana (parsimonious) belum tentu tidak lebih baik daripada model yang kompleks dimana hal ini terbukti pada kasus ini.

\section{KESIMPULAN}

Perbandingan model ARMA dan VAR dalam meramalkan return nilai tukar Rupiah dan return IHSG menghasilkan RMSE dan MAE terkecil masing-masing adalah model VAR(6) untuk Rupiah dan model ARMA $(2,2)$ untuk IHSG. Periode peramalan yang dilakukan dalam jangka waktu 10 hari memberikan gambaran bahwa VAR lebih adaptif dalam mengikuti pergerakan return nilai tukar dan IHSG dalam beberapa hari awal. Pelibatan variabel makroekonomi lainnya, seperti harga minyak dunia dan harga emas, dalam pemodelan dengan VAR diduga dapat meningkatkan akurasi peramalan. Hal ini disebabkan hasil penelitian menyiratkan adanya gangguan yang cukup tinggi pada model training dimana salah satunya dapat bersumber dari tidak dilibatkannya variabel yang memiliki kontribusi yang signifikan terhadap nilai tukar Rupiah dan IHSG.

\section{DAFTAR PUSTAKA}

Aladwani, J. (2017). Relationship between Exchange Rates and Stock Prices - GCC Perspectives. International Journal of Economics and Financial Issues, vol. 7, no. 2, pp. 11-24.

Appa, Y. (2014). Pengaruh Inflasi dan Kurs Rupiah/Dolar Amerika terhadap Indeks Harga Saham Gabungan (IHSG) di Bursa Efek Indonesia (BEI). eJournal Administrasi Bisnis, vol. 2, no. 4, pp. 498-512.

Fauziah, Moeljadi, dan Ratnawati, K. (2015). Dynamic Relationship between Exchange Rates and Stock Prices in Asia, 2009-2013. Journal of Economics, Finance and Accounting, vol. 2, no. 1, pp. 124-134.

Gujarati, D. N. (2004). Basic Econometrics, Fourth Edition. New York: McGraw-Hill.

Inci, A. C. dan Lee, B. S. (2011). Dynamic Relations between Stock Returns and Exchange Rate Changes. European Financial Management, vol. 20, no. 1, pp. 71-106.

Kumar, S., Managi, S., dan Matsuda, A. (2012). Stock Prices of Clean Energy Firms, Oil and Carbon Markets: A Vector Autoregressive Analysis. Energy Economics, vol. 34, no. 1, pp. 215-226.

Moore, T. dan Wang, P. (2014). Dynamic Linkage between Real Exchange Rates and Stock Prices: Evidence from Developed and Emerging Asian Markets. International Review of Economics and Finance, vol. 29, pp. 1-11.

Muchlas, Z. dan Alamsyah, A. R. (2015). Faktor-faktor yang Mempengaruhi Kurs Rupiah terhadap Dolar Amerika Pasca Krisis (2000-2010). Jurnal JIBEKA, vol. 9, no. 1, pp. 76-86.

Parsva, P. dan Tang, C. F. (2017). A Note on the Interaction between Stock Prices and Exchange Rates in Middle-East Economies. Economics Research-Ekonomska Istrazivanja, vol. 30, no. 1, pp. 836-844.

Rifai, N. A. K. (2019). Pendekatan Regresi Nonparametrik Kernel pada Data Indeks Harga Saham Gabungan. Statistika, vol. 19, no. 1, pp. 53-61.

Tsuji, C. (2015). Recent Comovements of the Yen-US Dollar Exchange Rate and Stock Prices in Japan. World Journal of Business and Management, vol. 1, no. 2, pp. 19-32.

Wei, W. W. S. (2006). Time Series Analysis: Univariate and Multivariate Methods, $2^{\text {nd }}$ Edition. New York: Pearson. 
Zhu, C., Byrd, R. H., dan Nocedal, J. (1997). L-BFGS-B: Algorithm 778: L-BFGS-B, Fortran Routines for Large Scale Bound Constrained Optimization. ACM Transactions on Mathematical Software, vol. 23, no. 4, pp. 550-560. 